\title{
Immunity to cytomegalovirus in early life
}

\author{
Ariane Huygens ${ }^{1}$, Nicolas Dauby ${ }^{1}$, David Vermijlen ${ }^{2}$ and Arnaud Marchant ${ }^{1}$ * \\ 1 Institute for Medical Immunology, Université Libre de Bruxelles, Charleroi, Belgium \\ 2 Faculty of Pharmacy, Université Libre de Bruxelles, Brussels, Belgium
}

Edited by:

Tobias R. Kollmann, University of

British Columbia, Canada

\section{Reviewed by:}

Soren Gantt, Child \& Family Research Institute, Canada

Philip Goulder, University of Oxford, UK

\section{*Correspondence:}

Arnaud Marchant, Institute for Medical Immunology, 8 rue Adrienne Bolland, Charleroi 6041, Belgium e-mail: arnaud.marchant@ulb.ac.be
Cytomegalovirus (CMV) is the most common congenital infection and is the leading non-genetic cause of neurological defects. CMV infection in early life is also associated with intense and prolonged viral excretion, indicating limited control of viral replication. This review summarizes our current understanding of the innate and adaptive immune responses to CMV infection during fetal life and infancy. It illustrates the fact that studies of congenital CMV infection have provided a proof of principle that the human fetus can develop anti-viral innate and adaptive immune responses, indicating that such responses should be inducible by vaccination in early life. The review also emphasizes the fact that our understanding of the mechanisms involved in symptomatic congenital CMV infection remains limited.

Keywords: cytomegalovirus, fetus, infant, $\gamma \delta$ T lymphocytes, $\alpha \beta$ T lymphocytes, B lymphocytes, NK cells, dendritic cells

\section{INTRODUCTION}

Cytomegaloviruses (CMV) belong to the betaherpesvirus family and establish a lifelong infection in their host. A number of species can be infected by CMV but each virus has adapted to its host. Specifically, the virus infecting humans is unable to establish a productive infection in animals (1). This review will be focused on human CMV infection and data from mouse or non-human primate CMV infection will be referred to when necessary. During the chronic phase of the human CMV infection, the virus becomes latent and reactivates sporadically. Viral excretion during the chronic phase can be related to the reactivation of the latent virus or to superinfections with new CMV strains (2).

Human CMV is the most common congenital infection, affecting $0.2-2.2 \%$ of all live births. Congenital CMV infection is the leading non-genetic cause of neurological defects, including mental retardation, cerebral palsy, and hearing impairment $(3,4)$. Approximately $10 \%$ of CMV-infected newborns present clinical signs and symptoms including small birth weight, petechiae, jaundice, hepatosplenomegaly, microcephaly, and seizures. Symptomatic infections are more common and more severe in newborns infected during the first trimester of gestation. The prognosis of symptomatic newborns is poor, as more than $90 \%$ have long-term sequelae and mortality rates among the most affected ranges from 10 to $30 \%$. Among asymptomatic newborns, $10-15 \%$ develops long-term sequelae during the first years of life, primarily hearing loss (5). Although $75-80 \%$ of infected newborns remain asymptomatic, they all excrete the virus for at least 5 years after birth (6), indicating a limited control of viral replication in some organs.

Post-natal CMV infection is usually asymptomatic but severe disease, including respiratory distress syndrome and sepsis, can develop in very premature babies (7). However, long-term sequelae have not been reported following post-natal CMV infection. Prolonged viral excretion lasting for at least 2 years is also observed following CMV infection in young children whereas it only lasts several months in immunocompetent adults $(8,9)$. Together, these observations indicate that the control of CMV replication is limited during early life as compared to adult life and that this reduced viral control is associated with an increased risk of symptomatic infection in the fetus and in the very premature newborn. Studies of the immune response to CMV infection in early life have provided important information on the development of the human immune system and on the capacity of the fetus to mount antiviral responses. However, our understanding of the pathogenesis of symptomatic infections and of the mechanism involved in the reduced control of viral replication remains limited. In this review, we summarize the available data on the innate and adaptive immune responses to CMV infection in early life as compared to adult life and we discuss their possible role in viral control and in the development of symptomatic infections.

\section{INNATE IMMUNE RESPONSES: $\gamma \delta$ T LYMPHOCYTES AND NATURAL KILLER CELLS}

$\gamma \delta \mathrm{T}$ lymphocytes and natural killer (NK) cells are innate lymphocytes that develop and differentiate early during fetal life (reviewed by Vermijlen and Prinz in this Research Topic). $\gamma \delta \mathrm{T}$ cells express a receptor formed of a $\gamma$ and a $\delta$ chain on their cell surface and are a prototype of unconventional $\mathrm{T}$ cells: they can react rapidly during the course of an immune response and they are major histocompatibility complex (MHC)-unrestricted. NK cells are innate lymphocytes that do not possess Rag recombinasedependent rearranged antigen receptors and that are activated by the balance between activating and inhibitory invariant receptors.

\section{$\gamma \delta$ T LYMPHOCYTES}

About 15 years ago, the group of Julie Déchanet-Merville reported that $\gamma \delta \mathrm{T}$ cells participate in the response to CMV in solid organ transplanted patients and that $\gamma \delta \mathrm{T}$ cell expansions are associated with a better clinical outcome $(10,11)$. More recently, evidence of a protective role of $\gamma \delta \mathrm{T}$ cells was obtained in the mouse model of CMV infection (Myriam Capone and Julie Déchanet-Merville; 
Michael Mach and Thomas Winkler; 6th International $\gamma \delta \mathrm{T}$ cell conference, May 2014, Chicago, USA). The $\gamma \delta$ T cells expanded by CMV in human adults are distinct from the phosphoantigenreactive $\mathrm{V} \gamma 9 \mathrm{~V} \delta 2 \mathrm{~T}$ cells and are collectively called $\mathrm{V} \delta 2$ negative $\left(\mathrm{V} \delta 2^{-}\right) \gamma \delta \mathrm{T}$ cells. Expansions of $\mathrm{V} \delta 2^{-}$cells are also observed in CMV-infected healthy adults and hematopoietic stem cell (HSC) transplanted patients (12-14). The expansion of T cells expressing particular combinations of $\mathrm{V} \gamma$ and $\mathrm{V} \delta$ chains and the restriction of the CDR3 repertoires among these cells strongly suggest an antigen-ligand interaction. Confirming this prediction, a ligand of a CMV-reactive $\mathrm{V} \gamma 4 \mathrm{~V} \delta 5 \mathrm{~T}$ cell receptor (TCR) derived from an adult patient was recently shown to be the endothelial protein C receptor (EPCR) $(15,16)$. EPCR is a MHC-like molecule that binds lipids analogously to the antigen-presenting molecule CD1d. However, the V $\gamma 4$ V 85 TCR binds EPCR in an antibody-like way, independently of lipids. The EPCR-dependent recognition of CMV-infected cells appears to be complex, as CMV infection does not induce EPCR expression itself but rather promotes the expression of a co-stimulatory complex promoting the detection of CMV infection by $\mathrm{V} \gamma 4 \mathrm{~V} \delta 5$ cells (15). Importantly, although the $\mathrm{V} \gamma 4 \mathrm{~V} \delta 5$ TCR binding EPCR was highly expanded in the single patient from whom it was derived, this particular clone has not been detected in other CMV-infected transplanted patients. This suggests that other $\gamma \delta$ TCR, that may recognize other ligands, participate in the response to CMV infection in adults.

We have reported that congenital CMV infection elicits a marked response of fetal $\gamma \delta$ T cells (17). The fetal $\gamma \delta$ T cell expansions induced by CMV are restricted to $\mathrm{V} \gamma 9^{-}$cells and express either $\mathrm{V} \delta 1, \mathrm{~V} \delta 2$, or $\mathrm{V} \delta 3$ chains. So, in contrast to adults, CMV induces the expansion of $\mathrm{V} \delta 2^{+}$cells in the fetus. Of note, these fetal $\mathrm{V} \delta 2^{+}$cells are $\mathrm{V} \gamma 9^{-}$and are therefore distinct from the "classical" phosphoantigen-responding $\mathrm{V} \gamma 9^{+} \mathrm{V} \delta 2^{+}$cells (17). As $\mathrm{V} \gamma 9^{-} \mathrm{V} \delta 2^{+} \mathrm{T}$ cells are very rare in CMV seronegative or CMV seropositive adults, it appears that CMV expands specific subsets of $\gamma \delta \mathrm{T}$ cells in the fetus $(10,18)$. Strikingly, the fetal $\gamma \delta$ $\mathrm{T}$ cell population expanded by CMV is also enriched in a public TCR formed by the $\mathrm{V} \gamma 8$ and the $\mathrm{V} \delta 1$ chains and containing the germ-line-encoded (no nucleotide addition between the V, $\mathrm{D}$, and $\mathrm{J}$ gene segments) CDR3 $\delta 1$-CALGELGDDKLIF/CDR3 $\gamma 8$ CATWDTTGWFKIF sequences. Cells expressing this public TCR were detected as early as 21 weeks of gestation (17). Recently, the same CDR3 $\gamma 8$-CATWDTTGWFKIF sequence was detected in healthy adults (of unknown CMV status) by high-throughput sequencing of the $\gamma$ gamma chain repertoire (19). Until now, the public CDR3 $\delta 1$ sequence detected in CMV-infected fetuses has not been detected in adults, either during primary of chronic CMV infection (Vermijlen et al., unpublished observation). These observations suggest important differences between the fetal and the adult $\gamma \delta \mathrm{T}$ cell repertoires (discussed in this Research Topic by Vermijlen and Prinz). This notion is supported by the fact that public CDR $3 \delta 2$ and CDR3 33 chains were also readily expanded in CMV-infected fetuses (17) (and Vermijlen et al., unpublished observation) but not in CMV-infected adults with solid organ transplantation $(10,12)$. Of note, the fetal public CDR3 sequences were completely germline-encoded, a characteristic that probably contributes to a higher probability of becoming a public CDR3 $\delta$ chain (17).
The fetal $\gamma \delta$ T cells induced by CMV infection express a type 1 effector phenotype, including the transcription factors T-bet and Eomes, the anti-viral cytokine IFN- $\gamma$, the cytolytic molecules perforin and granzymes as well as a range of NK receptors. Clones derived from CMV-infected newborns and expressing the public $\mathrm{V} \gamma 8 \mathrm{~V} \delta 1$ TCR produce IFN- $\gamma$ in a TCR/CD3-dependent manner upon incubation with CMV-infected target cells and show antiviral activity (17). These data indicate that functional fetal $\gamma \delta$ T cell responses can be generated during fetal life and suggest that this $\mathrm{T}$ cell subset could participate in the control of CMV replication. The role of $\gamma \delta$ T cells may be particularly important in early life as this subset develops earlier than conventional $\alpha \beta$ T cells during immune ontogeny in humans and mice. Accordingly, a central role of $\gamma \delta \mathrm{T}$ cells in immunity in early life has been demonstrated in a mouse model of intestinal parasite infection (20). However, as discussed later in this review, the possibility that $\gamma \delta \mathrm{T}$ cells as well as other components of the immune response, may contribute to fetal immunopathology cannot be excluded.

\section{NATURAL KILLER CELLS}

Natural killer cells play an important role in the immune response to human CMV infection, as indicated by the multiple immune evasion strategies developed by the virus to escape NK cell control (21). As in other viral infections, the control of CMV replication by NK cells depends on the balance between activating and inhibitory receptors. In the mouse, $\mathrm{NK}$ cell depletion was shown to result in decreased viral control indicating that the balance is in favor of NK cell activation (22). In humans, CMV infection has been associated with the expansion of $\mathrm{NKG}_{2} \mathrm{C}^{+} \mathrm{NK}$ cells in healthy subjects, in patients co-infected with HIV or hantavirus and in HSC-transplanted patients (23-28). NKG2C is an activating receptor recognizing HLA-E. Cell surface HLA-E expression is increased by the signal peptide of the human CMV UL40 protein, indicating that $\mathrm{NKG}_{2} \mathrm{C}^{+} \mathrm{NK}$ cells may be stimulated by $\mathrm{CMV}$-infected cells (29). More recently, a stable imprint of CMV infection has been described on the repertoire of killer cell immunoglobulin like receptors (KIRs) in healthy adults (30). Together, these observations indicate that specific subsets of NK cells are selectively expanded by human CMV infection. These cells may have a "memory" phenotype as it was described for mouse NK cells expressing the $\mathrm{Ly} 49 \mathrm{H}$ receptor and recognizing the $\mathrm{m} 157$ mouse CMV protein $(31,32)$.

Expansions of $\mathrm{NKG}_{2} \mathrm{C}^{+} \mathrm{NK}$ cells have also been observed in young children infected in utero with $\mathrm{CMV}$ and the frequencies of $\mathrm{NKG}_{2} \mathrm{C}^{+} \mathrm{NK}$ cells were higher in symptomatic as compared to asymptomatic children (33). The potential role of $\mathrm{NKG}^{+}$ $\mathrm{NK}$ cells in congenital CMV infection was evaluated by assessing the number of copies of the NKG2C gene. About $4 \%$ of Japanese and European adults have a complete deletion of the NKG2C gene and $32-34 \%$ of the populations are heterozygous $(34,35)$. The NKG2C deletion frequency was comparable in children with congenital CMV infection and in uninfected controls (33). However, homozygous children had higher numbers of circulating $\mathrm{NKG}_{2} \mathrm{C}^{+} \mathrm{NK}$ cells and total $\mathrm{NK}$ cells as compared to heterozygous children. These results suggest that NKG2C has an impact on NK cell homeostasis during CMV infection in early life but is not an essential determinant of CMV infection in exposed 
fetuses. This hypothesis is further supported by a recent report showing an association between deletions at the NKG2C locus and the frequency of differentiated $\mathrm{CD}_{5}{ }^{+} \mathrm{NK}$ cells in $\mathrm{CMV}$ infected children (36). The role of NK cells in the control of CMV infection in early life is supported by the report of a 3-month-old $\mathrm{T}^{-} \mathrm{B}^{+} \mathrm{NK}^{+}$SCID infant who presented with a CMV gastroenteritis that resolved spontaneously without anti-viral treatment (37). $\mathrm{NKG}_{2} \mathrm{C}^{+} \mathrm{NK}$ cells expressing a biased KIR repertoire were highly expanded in this patient and normalized when CMV viral load declined. Finally, CMV infection was shown to induce the maturation of NK cells after cord blood transplantation (28). Interestingly, this maturation is also observed in patients transplanted with $\mathrm{NKG} 2 \mathrm{C}-/-$ cord blood cells, indicating that activating KIRs can also be involved (38).

\section{INNATE IMMUNE RESPONSES: DENDRITIC CELLS}

Human dendritic cells (DCs) can be classified into myeloïd DCs (mDCs), whose main function is to prime and functionally polarize naive $\mathrm{T}$ lymphocytes, and plasmacytoïd DCs (pDCs) that produce high levels of type I interferons (IFNs). The interactions between CMV and human DCs have been studied in vitro using monocyte-derived DCs (moDCs) as a model of mDCs, CD34 ${ }^{+}$ bone marrow progenitor cell-derived Langerhans cell-type DCs (LDCs) as well as differentiated mDCs and pDCs purified from peripheral blood. In the presence of CMV, adult mDCs, moDCs, and pDCs produce high levels of pro-inflammatory cytokines and type I IFNs (39-41). This activation of cytokine production by moDCs and LDCs is associated with a decreased expression of $\mathrm{MHC}$ and co-stimulatory molecules and with a reduced capacity to stimulate $\mathrm{T}$ lymphocytes, suggesting an immune evasion mechanism developed by the virus $(42,43)$. However, experiments involving blood mDCs purified from healthy adults indicated no interference with $\mathrm{T}$ cell stimulation (40). Inhibition of $\mathrm{T}$ cell activating properties was also observed in in vitro models of DC infection by mouse CMV. In contrast, CMV markedly activates mouse DCs in vivo and enables them to stimulate potent $\mathrm{T}$ cell responses to the virus [reviewed in Ref. (44)]. These discrepancies between in vitro and in vivo data have been attributed to differences in the nature of the DCs involved and to differences in the frequency of cells infected by the virus (44).

Dendritic cells are detected early during the ontogeny of the human immune system but their functional program is different from that of adult DCs (reviewed in this Research Topic by De Kleer et al.). Most of our current understanding of the biology of DCs in early life comes from studies of the interactions between pathogen-associated molecular patterns (PAMPs) with specific innate receptors. In contrast, how DCs interact with complex pathogens remains poorly understood. In vitro studies have shown that cord blood-derived moDCs and adult moDCs are equally susceptible to CMV infection (39). As observed following activation with PAMPs, cord blood moDCs infected with CMV produce low levels of IL- 12 , IFN- $\beta$, and IFN- $\lambda 1$ as compared to adult cells (39). Similarly, cord blood pDCs produce lower amounts of IFN- $\alpha$ than adult pDCs upon in vitro incubation with CMV (45). In contrast, cord blood and adult moDCs infected with CMV produce similar levels of IFN- $\alpha$ and IFN-inducible genes, suggesting that mDCs may represent an important source of type I IFNs during
CMV infection (39). The reduced capacity of newborn moDCs to produce IL-12, IFN- $\beta$, and IFN- $\lambda 1$ in response to CMV infection probably involves a defective activation and nuclear translocation of IRF3. In contrast, the adult-like production of IFN- $\alpha$ may be related to IRF3-independent pathways (46). As discussed below, the reduced capacity of newborn DCs to produce IL-12 upon CMV infection may limit their capacity to promote the differentiation of Th1 cells and effector CD8 T cells. However, Th1 and effector CD8 $\mathrm{T}$ cell responses were shown to be induced independently of IL-12 in several experimental settings (47-50). Also, as indicated above, mouse studies have shown that the results obtained with in vitro models of CMV-DC interactions may not predict the responses of DCs to CMV infection in vivo.

\section{ADAPTIVE IMMUNE RESPONSES: $\alpha \beta$ T LYMPHOCYTES}

More than 20 years ago, studies of mouse CMV infection demonstrated the central role played by $\alpha \beta$ CD 4 and CD 8 T lymphocytes in the control of CMV infection (51-53). Clinical studies of adult transplanted patients indicated that the development of potent $\mathrm{T}$ cell responses to CMV is associated with a better clinical outcome. Furthermore, adoptive transfer of CMV-specific $\mathrm{T}$ cell clones demonstrated that $\mathrm{T}$ lymphocytes efficiently control CMV replication in humans (54-59). CD8 T lymphocytes are the dominant $\mathrm{T}$ cell population in the brain of neonatally infected mice and play a central role in the control of CMV replication in this organ (60).

The characteristics of CMV-specific T cells have been abundantly studied during the chronic phase of the infection and these studies have significantly contributed to our understanding of anti-viral immunity in humans. A central feature of the $\mathrm{T}$ cell response to $\mathrm{CMV}$ infection is that it involves large clonal expansions occupying an important fraction of the $\mathrm{T}$ cell pool. A comprehensive antigen repertoire analysis indicated that CMVspecific $\mathrm{T}$ cells comprise on average $10 \%$ of the total CD4 and CD8 memory T cell compartments in chronically infected healthy adults (61). A second feature of the T cell response to CMV is that it includes a large proportion of cells expressing a late differentiation phenotype characterized by the loss of expression of the CD27 and CD28 co-stimulatory molecules, a phenotype that is not or rarely induced by other viral infections $(62,63)$. CMV-specific CD4 and CD8 $\mathrm{T}$ cells produce high levels of anti-viral cytokines, including IFN- $\gamma$, TNF- $\alpha$, and MIP- $1 \beta$, following in vitro stimulation with viral antigens and both subsets express high levels of perforin and granzyme and are cytolytic $(64,65)$.

As primary CMV infection is usually asymptomatic in immunocompetent adults, studies of the early phase of the infection are relatively scarce and primarily involve populations of transplanted patients and of pregnant women screened for CMV infection. Primary CMV infection in adults is characterized by a period of intense viral excretion in several body fluids that lasts on average 6 months $(9,66)$. Viremia is controlled more rapidly than viral excretion in body fluids but can persist several weeks to months despite the presence of CMV-specific T cells (67). Indeed, high frequencies of CMV-specific CD4 and CD8 T cells appear early following primary CMV infection and the peak of their response is followed by a drop in peripheral blood viral load (68-70). The intense viral replication and excretion taking place during the first months of primary CMV infection is associated 
with a reduced capacity of CMV-specific CD4 T cells to proliferate and to produce IL-2 $(69,71)$. The acquisition of CD4 T cell proliferative responses correlates with the control of viremia and with a reduced risk of mother-to-fetus transmission of CMV (67). These defective IL-2 and proliferative responses are associated with a lower functional avidity of CMV-specific CD4 T cells and with a lower production of the anti-viral cytokines IFN- $\gamma$ and TNF- $\alpha$ as compared to the chronic stage of the infection (71). This state of functional unresponsiveness is associated with the upregulation of the inhibitory receptor program cell death (PD)-1 and inhibition of PD-1 increases CD4 T cell proliferative responses $(71,72)$. Together, these results indicate that the prolonged viral replication associated with primary CMV infection in adults is associated with a state of functional exhaustion of CD4 T cells similar to the one observed in patients with chronic HIV or hepatitis infections (73).

Historical studies detected weak or no $\mathrm{T}$ cell responses to congenital CMV infection. This defect lasted up to 5 years and was more severe in symptomatic children $(6,74)$. More recent studies using more sensitive assays demonstrated large responses of CD8 $\mathrm{T}$ cells following congenital or early post-natal CMV infection (8, 75-81). Fetal T cells activated in utero by CMV infection acquire a late differentiation phenotype $\left(\mathrm{CD} 27^{-} / \mathrm{CD} 28^{-}\right)$equivalent to the one acquired by adult $\mathrm{T}$ cells $(75,78,79,82)$. The differentiated CD8 $\mathrm{T}$ cell population contains large expansions of a restricted number of clones, strongly suggesting an antigen-specific rather than a bystander response (75). Direct evidence for antigenspecific responses was obtained using MHC class I tetramer staining and short-term peptide stimulation assays. CMV-specific fetal CD8 T cells produce anti-viral cytokines, including IFN- $\gamma$, TNF$\alpha$, and MIP- $1 \beta$ and express perforin-dependent cytolytic activity (75-77, 80). CD8 T cell responses to CMV have been detected in samples collected by cordocentesis as early as 22 and 28 weeks of gestation $(75,81)$. As single positive CD8 T cells can be detected in the human fetus by 14 weeks of gestation, it is likely that this subset participates in the defense against CMV infection from the second trimester of gestation (83). However, whether the magnitude and the quality of this response are equivalent to that of adults has not been studied in detail. Longitudinal studies of children infected in utero or soon after birth indicate that the frequency of CMVspecific IFN- $\gamma$-producing CD8 T cells as well as the repertoire of peptides they respond to increase during the first year of life (77, 78). As CMV-specific CD8 T cells were identified in these studies on the basis of their production of cytokines, it is unclear whether their increasing frequency with time after infection is related to cell multiplication or to an increased capacity to produce cytokines.

In contrast to CD8 $\mathrm{T}$ cell responses, very low or no CD4 $\mathrm{T}$ cell responses to CMV are usually detected in young children infected in utero or soon after birth $(8,74,80)$. Similar results are obtained using either proliferation or cytokine production assays following in vitro stimulation with CMV antigens. These observations contrast with the rapid expansion of CMV-specific CD4 T cells following primary infection in adults $(68-70,80)$. It is unclear from the current literature whether the low responses observed in early life involve a defective expansion of CMV-specific CD4 T cells or an impaired differentiation of effector cells. Our recent studies indicate that congenital CMV infection is associated with large oligoclonal expansions of CD4 T cells expressing a Th1 phenotype and having a restricted capacity to produce effector cytokines as compared to adult cells (Huygens et al., unpublished observations). These results suggest that primary CMV infection in adults and in the fetus is associated with the functional exhaustion of virus-specific CD4 $\mathrm{T}$ cells and that the magnitude of this phenomenon is particularly intense during fetal life. A more intense functional exhaustion of fetal T cells could be related to their prolonged exposure to higher antigen loads, as observed in chronic viral infections in humans and animals (73, 84-89). Indeed, clinical studies indicate that higher CMV viral loads are detected in the blood and urine of congenitally infected newborns and post-natally infected infants as compared to adults $(5,67,90$ 92). Further supporting this possibility, CMV-specific CD4 T cells responses increase during the first 2 years of life and the cessation of viruria was shown to be associated with the acquisition of proliferative T cell responses to CMV in congenitally infected children $(6,80)$.

It could be expected that the functional regulation of CD4 T cell responses to CMV in early life associated with high viral loads may also affect CD8 T cells. Indeed, our recent studies using MHC class I tetramer stainings indicate that CMV-specific fetal CD8 $\mathrm{T}$ cells have a reduced capacity to produce anti-viral cytokines as compared to adult cells (Huygens et al., unpublished observations). These results suggest that the increased frequency of cytokine-producing CD8 T cells observed during the first year after congenital CMV infection is related to an increase in their functional capacity $(77,78)$. Interestingly, a limited capacity of CD8 $\mathrm{T}$ cells to produce effector cytokines was also observed in children infected with HIV (93). Together, these results suggest that functional exhaustion may be an important mechanism limiting anti-viral $\alpha \beta$ T cell responses in early life.

\section{ADAPTIVE IMMUNE RESPONSES: B LYMPHOCYTES}

Studies of mouse CMV indicate that neutralizing antibodies protect against primary infection and reactivation by limiting viral dissemination in tissues and that transfer of B lymphocytes from immune animals protects immunocompromised hosts against lethal infection $(94,95)$. Antibodies also reduce CMV replication in the brain of neonatally infected mice and attenuate the morphological alterations caused by the virus (96). In humans, immunization with an adjuvanted CMV glycoprotein B vaccine primarily stimulating the production neutralizing antibodies protected against infection and viral replication $(97,98)$. On the other hand, CMV hyperimmune IgG (HIG) have been shown to provide protection against CMV-associated mortality in solid organ transplanted patients (99). HIG was also proposed for the prevention of mother-to-fetus transmission of CMV following primary infection during pregnancy but a recent randomized trial did not support this approach $(100,101)$. The impact of maternal antibodies on the post-natal transmission of CMV infection remains unclear. The avidity of breast milk IgG was shown to be inversely correlated with CMV milk viral load (102). However, intense transmission through breastfeeding is observed in areas where maternal CMV infection is universal and where babies are born with high levels of maternal antibodies (103). These observations suggest that maternal antibodies may not be sufficient to control the large viral load to which infants are exposed through breastfeeding. 
Despite the evidence that antibodies are an important component of immunity against CMV, very little is known about the $\mathrm{B}$ lymphocyte response to CMV infection in humans. In chronically infected adults, an important part of the antibody response is directed against tegument proteins. On the other hand, the envelope glycoprotein B and UL128-131 pentamer complex are important targets of antibodies neutralizing CMV infection of fibroblasts and epithelial cells, respectively (104). Intriguingly, primary CMV infection is associated with the rapid acquisition of antibodies directed against tegument proteins whereas envelope glycoprotein-specific antibodies are only acquired after several months (105). These observations suggest that CMV has developed evasion mechanisms delaying the acquisition of neutralizing antibodies and that this may favor virus dissemination. Supporting this hypothesis, the rapid acquisition of neutralizing antibodies, particularly against epithelial cell infection, was shown to be associated with a decreased risk of mother-to-fetus transmission of CMV (106). The mechanism involved in the delayed production of CMV envelope glycoprotein-specific antibodies has not been elucidated. We recently reported that primary CMV infection in pregnancy has an important impact on memory B cell subsets. Indeed, large and sustained expansions of virus-specific activated $\left(\mathrm{CD} 27^{+} \mathrm{CD} 20^{+} \mathrm{CD} 21^{\text {low }}\right)$ and atypical $\left(\mathrm{CD} 27^{-} \mathrm{CD} 20^{+} \mathrm{CD} 21^{\text {low }}\right)$ memory $\mathrm{B}$ cells are detected in pregnant women diagnosed with primary CMV infection, particularly in those who were viremic at the time of analysis (107). Increased frequencies of activated and atypical memory B cells have also been detected during HIV infection and have been suggested to play an important role in the defective antibody responses observed in these patients (108). As observed in HIV-infected patients, atypical memory B cells have a phenotype of exhausted cells during primary CMV infection. This phenotype is characterized by the upregulation of multiple inhibitory receptors and a decreased production of cytokines (107). Further studies are needed to define the role of memory B cell subsets in the delayed production of envelope glycoprotein-specific B cells following primary CMV infection.

Very little is known about the B cell response to CMV infection in early life. Studies have shown that CMV-specific IgM are commonly detected in congenitally infected newborns (109-111). As maternal IgG are transferred through the placenta from the second trimester of gestation, the capacity of the fetus to develop a class-switched antibody response and to produce neutralizing antibodies cannot be assessed by serology. Direct analyses of fetal $B$ cells will be required to address this important question. Several parameters are likely to limit B cell responses to CMV in early life. Firstly, vaccine studies indicated that the capacity of the newborn and the young infant to differentiate antibody-secreting plasma cells is lower than in adults. This limitation may be related to the intrinsic characteristics of B lymphocytes in early life and to a limited help provided by follicular helper $T$ cells, as observed in animal models (112). Secondly, the intense viral replication observed in $\mathrm{CMV}$-infected fetuses and young infants may induce an important functional exhaustion of B lymphocytes, as observed in adults (107). Finally, maternal antibodies transferred in utero may inhibit $\mathrm{B}$ cell responses to $\mathrm{CMV}$ in the fetus and in the young infant as they inhibit B cell responses to vaccines (reviewed by Niewiesk in this Research Topic). Study of the B cell response to CMV in early life should help us understand the potential contribution of this subset in viral control and may also provide important information on the ontogeny of B cell responses during fetal life.

\section{CONCLUDING REMARIKS AND PERSPECTIVES}

The study of the immune response to CMV infection during fetal life and infancy demonstrated that cellular immune responses can be induced very early during the ontogeny of the human immune system (Table 1). Effector $\gamma \delta$ T cells with anti-viral properties expand and differentiate during fetal life. Intriguingly, CMV expands different $\gamma \delta$ T cell populations in the fetus and in the adult. This may be related to differences in the repertoire of $\gamma \delta \mathrm{T}$ cells in early life and/or in the ligands induced by CMV in fetuses and adults (discussed by Vermijlen and Prinz in this Research Topic). Studies should be conducted to better understand the physiological development of this important $\mathrm{T}$ cell subset in humans. CMV infection in early life also activates NK cells with anti-viral potential. $\gamma \delta \mathrm{T}$ cells and NK cells are the first lymphocytes to develop during fetal life and could therefore play a very important role in the control of CMV infection during the first months of gestation. CMV infection during fetal life induced the expansion and the differentiation of effector CD4 and CD8 T cells. Effector CD8 T cell responses are also triggered by congenital HIV, Trypanosoma cruzi, and Toxoplasma gondii infections, indicating the capacity of the fetal immune system to respond to a range of different intracellular pathogens (113-118). These observations have important implications for the immunization of newborns against intracellular pathogens. Indeed, if effector $\mathrm{T}$ cell responses can be induced in utero following natural infections, similar responses should be inducible by neonatal vaccination.

The development of anti-viral effector $\mathrm{T}$ cells during fetal life also indicates that the fetal immune system is not systematically programed against inflammatory responses. Indeed, if the relative defect of cord blood DCs to produce type 1 IFNs and IL-12 can be extrapolated to DCs in the fetal organs, it does not appear to prevent the differentiation of pathogen-specific cytolytic CD8 T cells or Th1 cells (46). The differentiation of effector $\gamma \delta$ T cells may not require interactions with DCs as they may be directly stimulated by the ligands expressed by infected cells in tissues (119). Identification of the ligand(s) of the public $\gamma \delta$ TCR(s) expanded upon congenital CMV infection, will not only provide insight into the immune response toward CMV, but also into the general biology of $\gamma \delta \mathrm{T}$ cells. Once activated, $\gamma \delta \mathrm{T}$ cells, as well as NK cells, may in turn induce fetal DC maturation and thereby promote the differentiation of $\alpha \beta$ effector T cells (120-122). Also, the development of effector $\mathrm{T}$ cell responses against intracellular pathogens such as CMV does not appear to be prevented by the regulatory $\mathrm{T}$ cells and erythroid cells that are detected at high frequencies during fetal life and at birth $(123,124)$. It will be important to determine whether these fetal regulatory cells are activated by CMV infection and whether they impact effector $\mathrm{T}$ cell responses.

Large oligoclonal expansions of fetal CD8 and CD4 T cells are detected following congenital CMV infection. It is unclear whether the repertoire diversity of the fetal $\mathrm{T}$ cells activated by CMV is similar to the one triggered by the virus in adults. In neonatal mice, the activity of terminal deoxynucleotide transferase (TdT), the enzyme responsible for template-independent 
Table 1 | Immune response to CMV infection in early life: characteristics and gaps in knowledge.

Available information for early life infection

\section{INNATE IMMUNE RESPONSE}

- Expansion of fetal $\vee \gamma 9^{-}$cells with public TCRs (17)

- Anti-viral activity in vitro (17)

NK cells

- Expansion of NKG2C+ cells in infants (23-28)

Dendritic cells

- pDCs: limited production of IFN- $\alpha$ (45)

- moDCs: limited production of IL-12, IFN- $\beta$, and

IFN- $\lambda 1$ and adult-type production of IFN- $\alpha$ and

IFN-inducible genes (39) $\gamma \delta \mathrm{T}$ cells

\section{Gaps in knowledge}

- Evolution of repertoire from fetal to adult life

- Identification of fetal $\gamma \delta$ TCR ligands

- Role in viral control and in immunopathology following congenital infection

- Anti-viral activity of NK cells activated in early life

- Role in viral control and in immunopathology following congenital infection

- In vivo responses to early life infection

- Role of DC subsets in promoting adaptive immune responses in early life

\begin{tabular}{|c|c|c|}
\hline \multicolumn{3}{|c|}{ ADAPTIVE IMMUNE RESPONSE } \\
\hline CD8T cells & $\begin{array}{l}\text { - Large clonal expansions of differentiated cells with } \\
\text { anti-viral activity }(8,75-82)\end{array}$ & $\begin{array}{l}\text { - Functional capacity and repertoire diversity of fetal and infant cells } \\
\text { - Persistence of memory cells following infection in early life } \\
\text { - Role in viral control and in immunopathology following congenital } \\
\text { infection }\end{array}$ \\
\hline CD4T cells & $\begin{array}{l}\text { - Limited frequencies of cytokine-producing cells } \\
(8,74,80)\end{array}$ & $\begin{array}{l}\text { - Magnitude of response, repertoire diversity, and functional } \\
\text { programing of cells } \\
\text { - Mechanism underlying limited functional responses in the fetus and } \\
\text { young infant and the emergence of responses in older children } \\
\text { - Persistence of memory cells following infection in early life } \\
\text { - Role in viral control and in immunopathology following congenital } \\
\text { infection }\end{array}$ \\
\hline B cells & - IgM responses (109-111) & $\begin{array}{l}\text { - Development of effector cells and persistence of memory cells } \\
\text { following infection in early life } \\
\text { - Impact of maternal antibodies on fetal and infant B cell responses } \\
\text { - Role in viral control following infection in early life }\end{array}$ \\
\hline $\begin{array}{l}\text { Regulatory } T \text { cells } \\
\text { and erythroblasts }\end{array}$ & - No information available & $\begin{array}{l}\text { - In vivo responses to early life infection } \\
\text { - Role in controlling adaptive and innate responses in early life }\end{array}$ \\
\hline
\end{tabular}

nucleotide additions, is detected around 1 week of life and this activity correlates with the acquisition of an increased diversity of CDR3 sequences (125). In humans, TdT activity is detectable in the fetal thymus from the 20th week of gestation (126). As single positive thymocytes are already detected at 14 th week of gestation, the diversity of the $\mathrm{T}$ cell repertoire may increase during the second trimester of gestation in humans as it does during the first week after birth in the mouse and this may influence the recognition of pathogen-derived peptides (125). Another dimension of the $\alpha \beta \mathrm{T}$ cell response to CMV in early life that has not been studied is the persistence of effector $\mathrm{T}$ lymphocytes. Longitudinal analyses of $\mathrm{T}$ cell repertoire in kidney transplanted adults showed that CMVspecific CD8 $\mathrm{T}$ cell clones that emerge during the early phase of primary infection are maintained at high frequencies during the next 5 years (127). Recent mouse studies indicated that the rapid proliferation and differentiation of effector CD8 $\mathrm{T}$ cells impair the development of memory cells in early life (128). It will be important to determine whether a similar process limits the maintenance of anti-viral $\mathrm{T}$ cells in early life in humans.

The development of effector and memory $\mathrm{B}$ cell responses in early life remains poorly understood. This gap of knowledge remains a major limitation to the improvement of neonatal immunization strategies $(112,129)$. The study of the $\mathrm{B}$ cell response to congenital CMV infection could provide important insight into the molecular mechanisms controlling the differentiation and the survival of B lymphocytes in early life.

As discussed above, our recent observations indicate that effector CD8 and CD4 T cells are functionally exhausted during primary CMV infection and suggest that this phenomenon is particularly intense in early life. This intense degree of functional exhaustion may be related to a more intense CMV replication in the fetus and young infant than in the adult. A similar association between 
functional exhaustion and intense viral excretion was observed following primary CMV infection of juvenile rhesus macaques (130). As described in animal models of chronic viral infections, the reduced anti-viral properties of exhausted Tlymphocytes may, in turn, limit their capacity to control CMV replication. Directly assessing the impact of $\mathrm{T}$ cell exhaustion on $\mathrm{CMV}$ replication will require an animal model such as the one recently described in rhesus macaques (130). Of note, mouse studies have shown that CMV replication in the salivary glands and viral excretion in saliva are primarily controlled by CD4 $\mathrm{T}$ lymphocytes (52). Defining whether human $\mathrm{CD} 4 \mathrm{~T}$ cells are also central to the control of viral replication in salivary glands and in the kidney has potential implications for the design of vaccines aiming at reducing CMV transmission.

Finally, our understanding of the pathogenesis of symptomatic congenital CMV infection in humans remains very limited. However, mouse studies have provided important insights in the potential mechanisms involved and suggest that the immune response to CMV may play a dual role in the neurological pathology of neonatal mice by controlling CMV replication but also by inducing inflammatory responses promoting developmental abnormalities [reviewed in Ref. (131)]. The few histopathological studies of symptomatic human fetuses indicate that severe brain lesions, including microglial nodules, necrosis, and polymicrogyria, are associated with high tissue CMV viral load and with intense infiltration of CD8 T lymphocytes. Tissue necrosis may involve CD8 T cell-dependent immunopathology but may also be caused by the hypoxia resulting from the dysfunction of the CMV-infected placenta (132). Biomarker studies indicate that severe brain damage in the fetus is correlated with peripheral blood viral load and with the intensity of the immune response, measured as the plasma levels of $\beta 2$-microglobulin and anti-CMV IgM (91). Further studies are needed to increase our understanding of the role of the immune system in the pathogenesis of symptomatic congenital CMV infection and to identify markers predicting the development of neurological complications in utero and after birth. Ganciclovir is recommended for the prevention of long-term neurological sequelae in symptomatic infants (133). If the inflammatory response induced by CMV plays a role in the development of these sequelae, antiinflammatory agents may complement this therapeutic strategy (131). However, if research efforts are needed to better understand the pathogenesis of congenital CMV infection and to develop better therapies for affected children, the control of the disabilities caused by congenital infection will require the development of an efficient vaccine preventing the transmission of the virus to the fetus.

\section{ACKNOWLEDGMENTS}

Nicolas Dauby is a research fellow and Arnaud Marchant is a senior research associate at the Fonds de la Recherche Scientifique (F.R.S.FNRS) Belgium. Nicolas Dauby is the recipient of a scholarship from the Fondation Médicale Mathilde E. Horlait-Dapsens.

\section{REFERENCES}

1. Mocarski JES, Shenk T, Pass RF. Chapter 69 - cytomegaloviruses. In: Knipe DM, Howley PM, editors. Fields Virology. Philadelphia: Lippincott William \& Wilkins (2007). p. 2701-72.
2. Ross SA, Arora N, Novak Z, Fowler KB, Britt WJ, Boppana SB. Cytomegalovirus reinfections in healthy seroimmune women. J Infect Dis (2010) 201(3):386-9. doi:10.1086/649903

3. Stagno S, Pass RF, Dworsky ME, Henderson RE, Moore EG, Walton PD, et al. Congenital cytomegalovirus infection: the relative importance of primary and recurrent maternal infection. N Engl J Med (1982) 306(16):945-9. doi:10.1056/NEJM198204223061601

4. Dollard SC, Grosse SD, Ross DS. New estimates of the prevalence of neurological and sensory sequelae and mortality associated with congenital cytomegalovirus infection. Rev Med Virol (2007) 17(5):355-63. doi:10.1002/ rmv. 544

5. Britt WJ. Chapter 23 - cytomegalovirus. In: Remington JS, et al., editors. Infectious Diseases of the Fetus and Newborn. Philadelphia, PA: Elsevier Saunders (2011). p. 707-45.

6. Pass RF, Stagno S, Britt WJ, Alford CA. Specific cell-mediated immunity and the natural history of congenital infection with cytomegalovirus. J Infect Dis (1983) 148(6):953-61. doi:10.1093/infdis/148.6.953

7. Lanzieri TM, Dollard SC, Josephson CD, Schmid DS, Bialek SR. Breast milkacquired cytomegalovirus infection and disease in VLBW and premature infants. Pediatrics (2013) 131(6):e1937-45. doi:10.1542/peds.2013-0076

8. Tu W, Chen S, Sharp M, Dekker C, Manganello AM, Tongson EC, et al. Persistent and selective deficiency of CD4+ T cell immunity to cytomegalovirus in immunocompetent young children. J Immunol (2004) 172(5):3260-7. doi:10.4049/jimmunol.172.5.3260

9. Zanghellini F, Boppana SB, Emery VC, Griffiths PD, Pass RF. Asymptomatic primary cytomegalovirus infection: virologic and immunologic features. J Infect Dis (1999) 180(3):702-7. doi:10.1086/314939

10. Déchanet J, Merville P, Lim A, Retière C, Pitard V, Lafarge X, et al. Implication of gammadelta $\mathrm{T}$ cells in the human immune response to cytomegalovirus. J Clin Invest (1999) 103(10):1437-49. doi:10.1172/JCI5409

11. Lafarge X, Merville P, Cazin MC, Bergé F, Potaux L, Moreau JF, et al. Cytomegalovirus infection in transplant recipients resolves when circulating gammadelta $\mathrm{T}$ lymphocytes expand, suggesting a protective antiviral role. J Infect Dis (2001) 184(5):533-41. doi:10.1086/322843

12. Pitard V, Roumanes D, Lafarge X, Couzi L, Garrigue I, Lafon ME, et al. Long-term expansion of effector/memory Vdelta2-gammadelta $\mathrm{T}$ cells is a specific blood signature of CMV infection. Blood (2008) 112(4):1317-24. doi:10.1182/blood-2008-01-136713

13. Knight A, Madrigal AJ, Grace S, Sivakumaran J, Kottaridis P, Mackinnon S, et al. The role of Vdelta2-negative gammadelta T cells during cytomegalovirus reactivation in recipients of allogeneic stem cell transplantation. Blood (2010) 116(12):2164-72. doi:10.1182/blood-2010-01-255166

14. Scheper W, van Dorp S, Kersting S, Pietersma F, Lindemans C, Hol S, et al. GammadeltaT cells elicited by CMV reactivation after allo-SCT cross-recognize CMV and leukemia. Leukemia (2013) 27(6):1328-38. doi:10.1038/leu.2012. 374

15. Willcox CR, Pitard V, Netzer S, Couzi L, Salim M, Silberzahn T, et al. Cytomegalovirus and tumor stress surveillance by binding of a human gammadelta $\mathrm{T}$ cell antigen receptor to endothelial protein $\mathrm{C}$ receptor. Nat Immunol (2012) 13(9):872-9. doi:10.1038/ni.2394

16. Halary F, Pitard V, Dlubek D, Krzysiek R, de la Salle H, Merville P, et al. Shared reactivity of $\mathrm{V}\{$ delta $2($ neg) \{gamma\}\{delta\} $\mathrm{T}$ cells against cytomegalovirus-infected cells and tumor intestinal epithelial cells. J Exp Med (2005) 201(10):1567-78. doi:10.1084/jem.20041851

17. Vermijlen D, Brouwer M, Donner C, Liesnard C, Tackoen M, Van Rysselberge $\mathrm{M}$, et al. Human cytomegalovirus elicits fetal gammadelta $\mathrm{T}$ cell responses in utero. J Exp Med (2010) 207(4):807-21. doi:10.1084/jem.20090348

18. Morita CT, Parker CM, Brenner MB, Band H. TCR usage and functional capabilities of human gamma delta $\mathrm{T}$ cells at birth. J Immunol (1994) 153(9):3979-88.

19. Sherwood AM, Desmarais C, Livingston RJ, Andriesen J, Haussler M, Carlson CS, et al. Deep sequencing of the human TCRgamma and TCRbeta repertoires suggests that TCRbeta rearranges after alphabeta and gammadelta T cell commitment. Sci Transl Med (2011) 3(90):90ra61. doi:10.1126/scitranslmed. 3002536

20. Ramsburg E, Tigelaar R, Craft J, Hayday A. Age-dependent requirement for gammadelta $\mathrm{T}$ cells in the primary but not secondary protective immune response against an intestinal parasite. J Exp Med (2003) 198(9):1403-14. doi:10.1084/jem.20030050 
21. Lopez-Botet M, Muntasell A, Vilches C. The CD94/NKG2C+ NK-cell subset on the edge of innate and adaptive immunity to human cytomegalovirus infection. Semin Immunol (2014) 26(2):145-51. doi:10.1016/j.smim.2014.03.002

22. Tyznik AJ, Verma S, Wang Q, Kronenberg M, Benedict CA. Distinct requirements for activation of NKT and NK cells during viral infection. J Immunol (2014) 192(8):3676-85. doi:10.4049/jimmunol.1300837

23. Gumá M, Angulo A, Vilches C, Gómez-Lozano N, Malats N, López-Botet M. Imprint of human cytomegalovirus infection on the NK cell receptor repertoire. Blood (2004) 104(12):3664-71. doi:10.1182/blood-2004-05-2058

24. Gumá M, Cabrera C, Erkizia I, Bofill M, Clotet B, Ruiz L, et al. Human cytomegalovirus infection is associated with increased proportions of NK cells that express the CD94/NKG2C receptor in aviremic HIV-1-positive patients. J Infect Dis (2006) 194(1):38-41. doi:10.1086/504719

25. Björkström NK, Svensson A, Malmberg KJ, Eriksson K, Ljunggren HG. Characterization of natural killer cell phenotype and function during recurrent human HSV-2 infection. PLoS One (2011) 6(11):e27664. doi:10.1371/journal. pone. 0027664

26. Foley B, Cooley S, Verneris MR, Pitt M, Curtsinger J, Luo X, et al. Cytomegalovirus reactivation after allogeneic transplantation promotes a lasting increase in educated $\mathrm{NKG} 2 \mathrm{C}+$ natural killer cells with potent function. Blood (2012) 119(11):2665-74. doi:10.1182/blood-2011-10-386995

27. Foley B, Cooley S, Verneris MR, Curtsinger J, Luo X, Waller EK, et al. Human cytomegalovirus (CMV)-induced memory-like NKG2C(+) NK cells are transplantable and expand in vivo in response to recipient CMV antigen. J Immunol (2012) 189(10):5082-8. doi:10.4049/jimmunol.1201964

28. Della Chiesa M, Falco M, Podestà M, Locatelli F, Moretta L, Frassoni F, et al. Phenotypic and functional heterogeneity of human NK cells developing after umbilical cord blood transplantation: a role for human cytomegalovirus? Blood (2012) 119(2):399-410. doi:10.1182/blood-2011-08-372003

29. Tomasec P, Braud VM, Rickards C, Powell MB, McSharry BP, Gadola S, et al. Surface expression of HLA-E, an inhibitor of natural killer cells, enhanced by human cytomegalovirus gpUL40. Science (2000) 287(5455):1031. doi:10.1126/ science.287.5455.1031

30. Béziat V, Liu LL, Malmberg JA, Ivarsson MA, Sohlberg E, Björklund AT, et al. NK cell responses to cytomegalovirus infection lead to stable imprints in the human KIR repertoire and involve activating KIRs. Blood (2013) 121(14):2678-88. doi:10.1182/blood-2012-10-459545

31. Paust S, von Andrian UH. Natural killer cell memory. Nat Immunol (2011) 12(6):500-8. doi:10.1038/ni.2032

32. Min-Oo G, Bezman NA, Madera S, Sun JC, Lanier LL. Proapoptotic Bim regulates antigen-specific NK cell contraction and the generation of the memory NK cell pool after cytomegalovirus infection. J Exp Med (2014) 211(7):1289-96. doi:10.1084/jem.20132459

33. Noyola DE, Fortuny C, Muntasell A, Noguera-Julian A, Muñoz-Almagro C, Alarcón A, et al. Influence of congenital human cytomegalovirus infection and the NKG2C genotype on NK-cell subset distribution in children. Eur J Immunol (2012) 42(12):3256-66. doi:10.1002/eji.201242752

34. Moraru M, Cisneros E, Gómez-Lozano N, de Pablo R, Portero F, Cañizares M, et al. Host genetic factors in susceptibility to herpes simplex type 1 virus infection: contribution of polymorphic genes at the interface of innate and adaptive immunity. J Immunol (2012) 188(9):4412-20. doi:10.4049/jimmunol.1103434

35. Miyashita R, Tsuchiya N, Hikami K, Kuroki K, Fukazawa T, Bijl M, et al. Molecular genetic analyses of human NKG2C (KLRC2) gene deletion. Int Immunol (2004) 16(1):163-8. doi:10.1093/intimm/dxh013

36. Goodier MR, White MJ, Darboe A, Nielsen CM, Goncalves A, Bottomley C, et al. Rapid natural killer cell differentiation in a population with near universal human cytomegalovirus infection is attenuated by NKG2C deletions. Blood (2014) 124(14):2213-22. doi:10.1182/blood-2014-05-576124

37. Kuijpers TW, Baars PA, Dantin C, van den Burg M, van Lier RA, Roosnek E. Human NK cells can control CMV infection in the absence of T cells. Blood (2008) 112(3):914-5. doi:10.1182/blood-2008-05-157354

38. Della Chiesa M, Falco M, Bertaina A, Muccio L, Alicata C, Frassoni F, et al. Human cytomegalovirus infection promotes rapid maturation of NK cells expressing activating killer Ig-like receptor in patients transplanted with NKG2C-/- umbilical cord blood. J Immunol (2014) 192(4):1471-9. doi:10.4049/jimmunol.1302053

39. Renneson J, Dutta B, Goriely S, Danis B, Lecomte S, Laes JF, et al. IL-12 and type I IFN response of neonatal myeloid DC to human CMV infection. Eur J Immunol (2009) 39(10):2789-99. doi:10.1002/eji.200939414
40. Kvale EØ, Dalgaard J, Lund-Johansen F, Rollag H, Farkas L, Midtvedt K, et al. CD11c+ dendritic cells and plasmacytoid DCs are activated by human cytomegalovirus and retain efficient $\mathrm{T}$ cell-stimulatory capability upon infection. Blood (2006) 107(5):2022-9. doi:10.1182/blood-2005-05-2016

41. Varani S, Cederarv M, Feld S, Tammik C, Frascaroli G, Landini MP, et al. Human cytomegalovirus differentially controls $\mathrm{B}$ cell and $\mathrm{T}$ cell responses through effects on plasmacytoid dendritic cells. J Immunol (2007) 179(11):7767-76. doi:10.4049/jimmunol.179.11.7767

42. Moutaftsi M, Mehl AM, Borysiewicz LK, Tabi Z. Human cytomegalovirus inhibits maturation and impairs function of monocyte-derived dendritic cells. Blood (2002) 99(8):2913-21. doi:10.1182/blood.V99.8.2913

43. Hertel L, Lacaille VG, Strobl H, Mellins ED, Mocarski ES. Susceptibility of immature and mature Langerhans cell-type dendritic cells to infection and immunomodulation by human cytomegalovirus. J Virol (2003) 77(13):7563-74. doi:10.1128/JVI.77.13.7563-7574.2003

44. Alexandre YO, Cocita CD, Ghilas S, Dalod M. Deciphering the role of DC subsets in MCMV infection to better understand immune protection against viral infections. Front Microbiol (2014) 5:378. doi:10.3389/fmicb.2014. 00378

45. Danis B, George TC, Goriely S, Dutta B, Renneson J, Gatto L, et al. Interferon regulatory factor 7-mediated responses are defective in cord blood plasmacytoid dendritic cells. Eur J Immunol (2008) 38(2):507-17. doi:10.1002/eji. 200737760

46. Kollmann TR, Levy O, Montgomery RR, Goriely S. Innate immune function by toll-like receptors: distinct responses in newborns and the elderly. Immunity (2012) 37(5):771-83. doi:10.1016/j.immuni.2012.10.014

47. Schijns VE, Haagmans BL, Wierda CM, Kruithof B, Heijnen IA, Alber G, et al. Mice lacking IL-12 develop polarized Th1 cells during viral infection. JImmunol (1998) 160(8):3958-64.

48. Xing Z, Zganiacz A, Wang J, Divangahi M, Nawaz F. IL-12-independent Th1-type immune responses to respiratory viral infection: requirement of IL-18 for IFN-gamma release in the lung but not for the differentiation of viral-reactive Th1-type lymphocytes. J Immunol (2000) 164(5):2575-84. doi:10.4049/jimmunol.164.5.2575

49. Oxenius A, Karrer U, Zinkernagel RM, Hengartner H. IL-12 is not required for induction of type 1 cytokine responses in viral infections. J Immunol (1999) 162(2):965-73.

50. Kolumam GA, Thomas S, Thompson LJ, Sprent J, Murali-Krishna K. Type I interferons act directly on CD8 T cells to allow clonal expansion and memory formation in response to viral infection. J Exp Med (2005) 202(5):637-50. doi:10.1084/jem.20050821

51. Reddehase MJ, Weiland F, Münch K, Jonjic S, Lüske A, Koszinowski UH. Interstitial murine cytomegalovirus pneumonia after irradiation: characterization of cells that limit viral replication during established infection of the lungs. J Virol (1985) 55(2):264-73.

52. Jonjic S, Mutter W, Weiland F, Reddehase MJ, Koszinowski UH. Site-restricted persistent cytomegalovirus infection after selective long-term depletion of CD4+ T lymphocytes. J Exp Med (1989) 169(4):1199-212. doi:10.1084/jem. 169.4.1199

53. Polic B, Hengel H, Krmpotic A, Trgovcich J, Pavic I, Luccaronin P, et al. Hierarchical and redundant lymphocyte subset control precludes cytomegalovirus replication during latent infection. J Exp Med (1998) 188(6):1047-54. doi:10. 1084/jem.188.6.1047

54. Gamadia LE, Remmerswaal EB, Weel JF, Bemelman F, van Lier RA, Ten Berge IJ. Primary immune responses to human CMV: a critical role for IFN-gammaproducing CD4+ T cells in protection against CMV disease. Blood (2003) 101(7):2686-92. doi:10.1182/blood-2002-08-2502

55. Pourgheysari B, Piper KP, McLarnon A, Arrazi J, Bruton R, Clark F, et al. Early reconstitution of effector memory CD4+CMV-specific T cells protects against CMV reactivation following allogeneic SCT. Bone Marrow Transplant (2009) 43(11):853-61. doi:10.1038/bmt.2008.403

56. Einsele H, Roosnek E, Rufer N, Sinzger C, Riegler S, Löffler J, et al. Infusion of cytomegalovirus (CMV)-specific T cells for the treatment of CMV infection not responding to antiviral chemotherapy. Blood (2002) 99(11):3916-22. doi:10.1182/blood.V99.11.3916

57. Walter EA, Greenberg PD, Gilbert MJ, Finch RJ, Watanabe KS, Thomas ED, et al. Reconstitution of cellular immunity against cytomegalovirus in recipients of allogeneic bone marrow by transfer of T-cell clones from the donor. $N$ Engl J Med (1995) 333(16):1038-44. doi:10.1056/NEJM199510193331603 
58. Reusser P, Riddell SR, Meyers JD, Greenberg PD. Cytotoxic T-lymphocyte response to cytomegalovirus after human allogeneic bone marrow transplantation: pattern of recovery and correlation with cytomegalovirus infection and disease. Blood (1991) 78(5):1373-80.

59. Riddell SR, Watanabe KS, Goodrich JM, Li CR, Agha ME, Greenberg PD. Restoration of viral immunity in immunodeficient humans by the adoptive transfer of T cell clones. Science (1992) 257(5067):238-41. doi:10.1126/science. 1352912

60. Bantug GR, Cekinovic D, Bradford R, Koontz T, Jonjic S, Britt WJ. CD8+ $\mathrm{T}$ lymphocytes control murine cytomegalovirus replication in the central nervous system of newborn animals. J Immunol (2008) 181(3):2111-23. doi:10.4049/jimmunol.181.3.2111

61. Sylwester AW, Mitchell BL, Edgar JB, Taormina C, Pelte C, Ruchti F, et al. Broadly targeted human cytomegalovirus-specific CD4+ and CD8+ T cells dominate the memory compartments of exposed subjects. J Exp Med (2005) 202(5):673-85. doi:10.1084/jem.20050882

62. Appay V, Dunbar PR, Callan M, Klenerman P, Gillespie GM, Papagno L, et al. Memory CD8+ T cells vary in differentiation phenotype in different persistent virus infections. Nat Med (2002) 8(4):379-85. doi:10.1038/nm0402-379

63. Appay V, van Lier RA, Sallusto F, Roederer M. Phenotype and function of human T lymphocyte subsets: consensus and issues. Cytometry A (2008) 73(11):975-83. doi:10.1002/cyto.a.20643

64. van Leeuwen EM, Remmerswaal EB, Vossen MT, Rowshani AT, Wertheimvan Dillen PM, van Lier RA, et al. Emergence of a CD4+CD28-granzyme $\mathrm{B}+$, cytomegalovirus-specific $\mathrm{T}$ cell subset after recovery of primary cytomegalovirus infection. J Immunol (2004) 173(3):1834-41. doi:10.4049/ jimmunol.173.3.1834

65. Appay V, Rowland-Jones SL. Lessons from the study of T-cell differentiation in persistent human virus infection. Semin Immunol (2004) 16(3):205-12. doi:10.1016/j.smim.2004.02.007

66. Revello MG, Zavattoni M, Sarasini A, Percivalle E, Simoncini L, Gerna G. Human cytomegalovirus in blood of immunocompetent persons during primary infection: prognostic implications for pregnancy. J Infect Dis (1998) 177(5):1170-5. doi:10.1086/515277

67. Lilleri D, Fornara C, Furione M, Zavattoni M, Revello MG, Gerna G. Development of human cytomegalovirus-specific $\mathrm{T}$ cell immunity during primary infection of pregnant women and its correlation with virus transmission to the fetus. J Infect Dis (2007) 195(7):1062-70. doi:10.1086/512245

68. Rentenaar RJ, Gamadia LE, van DerHoek N, van Diepen FN, Boom R, Weel JF, et al. Development of virus-specific CD4(+) T cells during primary cytomegalovirus infection. J Clin Invest (2000) 105(4):541-8. doi:10.1172/ JCI8229

69. Fornara C, Lilleri D, Revello MG, Furione M, Zavattoni M, Lenta E, et al. Kinetics of effector functions and phenotype of virus-specific and gammadelta $\mathrm{T}$ lymphocytes in primary human cytomegalovirus infection during pregnancy. J Clin Immunol (2011) 31(6):1054-64. doi:10.1007/s10875-0119577-8

70. Lilleri D, Fornara C, Revello MG, Gerna G. Human cytomegalovirus-specific memory CD8+ and CD4+ T cell differentiation after primary infection. J Infect Dis (2008) 198(4):536-43. doi:10.1086/590118

71. Antoine P, Olislagers V, Huygens A, Lecomte S, Liesnard C, Donner C, et al. Functional exhaustion of CD4+ $\mathrm{T}$ Lymphocytes during primary cytomegalovirus infection. J Immunol (2012) 189(5):2665-72. doi:10.4049/ jimmunol.1101165

72. Sester U, Presser D, Dirks J, Gärtner BC, Köhler H, Sester M. PD-1 expression and IL-2 loss of cytomegalovirus-specific T cells correlates with viremia and reversible functional anergy. Am J Transplant (2008) 8(7):1486-97. doi:10.1111/j.1600-6143.2008.02279.x

73. Wherry EJ. T cell exhaustion. Nat Immunol (2011) 12(6):492-9. doi:10.1038/ ni.2035

74. Starr SE, Tolpin MD, Friedman HM, Paucker K, Plotkin SA. Impaired cellular immunity to cytomegalovirus in congenitally infected children and their mothers. J Infect Dis (1979) 140(4):500-5. doi:10.1093/infdis/140.4.500

75. Marchant A, Appay V, Van Der Sande M, Dulphy N, Liesnard C, Kidd M, et al. Mature CD8(+) T lymphocyte response to viral infection during fetal life. JClin Invest (2003) 111(11):1747-55. doi:10.1172/JCI200317470

76. Gibson L, Piccinini G, Lilleri D, Revello MG, Wang Z, Markel S, et al. Human cytomegalovirus proteins pp65 and immediate early protein 1 are common targets for CD8+ $\mathrm{T}$ cell responses in children with congenital or postnatal human cytomegalovirus infection. J Immunol (2004) 172(4):2256-64. doi:10.4049/jimmunol.172.4.2256

77. Gibson L, Dooley S, Trzmielina S, Somasundaran M, Fisher D, Revello MG, et al. Cytomegalovirus (CMV) IE1- and pp65-specific CD8+ T cell responses broaden over time after primary CMV infection in infants. J Infect Dis (2007) 195(12):1789-98. doi:10.1086/518042

78. Miles DJ, van der Sande M, Jeffries D, Kaye S, Ismaili J, Ojuola O, et al. Cytomegalovirus infection in Gambian infants leads to profound CD8 T-cell differentiation. J Virol (2007) 81(11):5766-76. doi:10.1128/JVI.00052-07

79. Pedron B, Guerin V, Jacquemard F, Munier A, Daffos F, Thulliez P, et al. Comparison of CD8+ T Cell responses to cytomegalovirus between human fetuses and their transmitter mothers. J Infect Dis (2007) 196(7):1033-43. doi:10.1086/521196

80. Lidehäll AK, Engman ML, Sund F, Malm G, Lewensohn-Fuchs I, Ewald U, et al. Cytomegalovirus-specific CD4 and CD8 T cell responses in infants and children. Scand J Immunol (2013) 77(2):135-43. doi:10.1111/sji.12013

81. Elbou Ould MA, Luton D, Yadini M, Pedron B, Aujard Y, Jacqz-Aigrain E, et al. Cellular immune response of fetuses to cytomegalovirus. Pediatr Res (2004) 55(2):280-6. doi:10.1203/01.PDR.0000104150.85437.FE

82. Miles DJ, Sanneh M, Holder B, Crozier S, Nyamweya S, Touray ES, et al. Cytomegalovirus infection induces T-cell differentiation without impairing antigen-specific responses in Gambian infants. Immunology (2008) 124(3):388-400. doi:10.1111/j.1365-2567.2007.02787.x

83. Haddad R, Guimiot F, Six E, Jourquin F, Setterblad N, Kahn E, et al. Dynamics of thymus-colonizing cells during human development. Immunity (2006) 24(2):217-30. doi:10.1016/j.immuni.2006.01.008

84. Mueller SN, Ahmed R. High antigen levels are the cause of T cell exhaustion during chronic viral infection. Proc Natl Acad Sci US A (2009) 106(21):8623-8. doi:10.1073/pnas.0809818106

85. Frebel H, Richter K, Oxenius A. How chronic viral infections impact on antigenspecific T-cell responses. Eur J Immunol (2010) 40(3):654-63. doi:10.1002/eji. 200940102

86. Bucks CM, Norton JA, Boesteanu AC, Mueller YM, Katsikis PD. Chronic antigen stimulation alone is sufficient to drive CD8+ T cell exhaustion. J Immunol (2009) 182(11):6697-708. doi:10.4049/jimmunol.0800997

87. Rehr M, Cahenzli J, Haas A, Price DA, Gostick E, Huber M, et al. Emergence of polyfunctional CD8+ T cells after prolonged suppression of human immunodeficiency virus replication by antiretroviral therapy. J Virol (2008) 82(7):3391-404. doi:10.1128/JVI.02383-07

88. Day EK, Carmichael AJ, ten Berge IJ, Waller EC, Sissons JG, Wills MR. Rapid CD8+ $\mathrm{T}$ cell repertoire focusing and selection of high-affinity clones into memory following primary infection with a persistent human virus: human cytomegalovirus. J Immunol (2007) 179(5):3203-13. doi:10.4049/jimmunol. 179.5.3203

89. Petrovas C, Casazza JP, Brenchley JM, Price DA, Gostick E, Adams WC, et al. PD-1 is a regulator of virus-specific CD8+ T cell survival in HIV infection. J Exp Med (2006) 203(10):2281-92. doi:10.1084/jem.20061496

90. Revello MG, Lilleri D, Zavattoni M, Furione M, Genini E, Comolli G, et al. Lymphoproliferative response in primary human cytomegalovirus (HCMV) infection is delayed in HCMV transmitter mothers. J Infect Dis (2006) 193(2):269-76. doi:10.1086/498872

91. Fabbri E, Revello MG, Furione M, Zavattoni M, Lilleri D, Tassis B, et al. Prognostic markers of symptomatic congenital human cytomegalovirus infection in fetal blood. BJOG (2011) 118(4):448-56. doi:10.1111/j.1471-0528. 2010.02822.x

92. Guerra B, Lazzarotto T, Quarta S, Lanari M, Bovicelli L, Nicolosi A, et al. Prenatal diagnosis of symptomatic congenital cytomegalovirus infection. Am JObstet Gynecol (2000) 183(2):476-82. doi:10.1067/mob.2000.106347

93. Scott-Algara D, Buseyne F, Porrot F, Corre B, Bellal N, Rouzioux C, et al. Not all tetramer binding CD8 $+\mathrm{T}$ cells can produce cytokines and chemokines involved in the effector functions of virus-specific CD8+ T lymphocytes in HIV-1 infected children. J Clin Immunol (2005) 25(1):57-67. doi:10.1007/ s10875-005-0358-3

94. Jonjic S, Pavic I, Polic B, Crnkovic I, Lucin P, Koszinowski UH. Antibodies are not essential for the resolution of primary cytomegalovirus infection but limit dissemination of recurrent virus. J Exp Med (1994) 179(5):1713-7. doi:10.1084/jem.179.5.1713 
95. Wirtz N, Schader SI, Holtappels R, Simon CO, Lemmermann NA, Reddehase MJ, et al. Polyclonal cytomegalovirus-specific antibodies not only prevent virus dissemination from the portal of entry but also inhibit focal virus spread within target tissues. Med Microbiol Immunol (2008) 197(2):151-8. doi:10.1007/s00430-008-0095-0

96. Cekinovic D, Golemac M, Pugel EP, Tomac J, Cicin-Sain L, Slavuljica I, et al. Passive immunization reduces murine cytomegalovirus-induced brain pathology in newborn mice. J Virol (2008) 82(24):12172-80. doi:10.1128/JVI. 01214-08

97. Griffiths PD, Stanton A, McCarrell E, Smith C, Osman M, Harber M, et al. Cytomegalovirus glycoprotein-B vaccine with MF59 adjuvant in transplant recipients: a phase 2 randomised placebo-controlled trial. Lancet (2011) 377(9773):1256-63. doi:10.1016/S0140-6736(11)60136-0

98. Pass RF, Zhang C, Evans A, Simpson T, Andrews W, Huang ML, et al. Vaccine prevention of maternal cytomegalovirus infection. N Engl J Med (2009) 360(12):1191-9. doi:10.1056/NEJMoa0804749

99. Hodson EM, Jones CA, Strippoli GF, Webster AC, Craig JC. Immunoglobulins, vaccines or interferon for preventing cytomegalovirus disease in solid organ transplant recipients. Cochrane Database Syst Rev (2007) (2):CD005129. doi:10.1002/14651858.CD005129.pub2

100. Nigro G, Adler SP, La Torre R, Best AM, Congenital Cytomegalovirus Collaborating Group. Passive immunization during pregnancy for congenital cytomegalovirus infection. N Engl J Med (2005) 353(13):1350-62. doi:10.1056/ NEJMoa043337

101. Revello MG, Lazzarotto T, Guerra B, Spinillo A, Ferrazzi E, Kustermann A, et al. A randomized trial of hyperimmune globulin to prevent congenital cytomegalovirus. N Engl J Med (2014) 370(14):1316-26. doi:10.1056/ NEJMoa1310214

102. Ehlinger EP, Webster EM, Kang HH, Cangialose A, Simmons AC, Barbas KH, et al. Maternal cytomegalovirus-specific immune responses and symptomatic postnatal cytomegalovirus transmission in very low-birth-weight preterm infants. J Infect Dis (2011) 204(11):1672-82. doi:10.1093/infdis/jir632

103. Kaye S, Miles D, Antoine P, Burny W, Ojuola B, Kaye P, et al. Virological and immunological correlates of mother-to-child transmission of cytomegalovirus in The Gambia. J Infect Dis (2008) 197(9):1307-14. doi:10.1086/586715

104. Ryckman BJ, Rainish BL, Chase MC, Borton JA, Nelson JA, Jarvis MA, et al. Characterization of the human cytomegalovirus $\mathrm{gH} / \mathrm{gL} / \mathrm{UL} 128-131 \mathrm{com}-$ plex that mediates entry into epithelial and endothelial cells. J Virol (2008) 82(1):60-70. doi:10.1128/JVI.01910-07

105. Schoppel K, Kropff B, Schmidt C, Vornhagen R, Mach M. The humoral immune response against human cytomegalovirus is characterized by a delayed synthesis of glycoprotein-specific antibodies. J Infect Dis (1997) 175(3):533-44. doi:10.1093/infdis/175.3.533

106. Lilleri D, Kabanova A, Revello MG, Percivalle E, Sarasini A, Genini E, et al. Fetal human cytomegalovirus transmission correlates with delayed maternal antibodies to $\mathrm{gH} / \mathrm{gL} / \mathrm{pUL} 128-130-131$ complex during primary infection. PLoS One (2013) 8(3):e59863. doi:10.1371/journal.pone.0059863

107. Dauby N, Kummert C, Lecomte S, Liesnard C, Delforge ML, Donner C, et al. Primary human cytomegalovirus infection induces the expansion of virus-specific activated and atypical memory B cells. J Infect Dis (2014) 210(8):1275-85. doi:10.1093/infdis/jiu255

108. Moir S, Fauci AS. B cells in HIV infection and disease. Nat Rev Immunol (2009) 9(4):235-45. doi:10.1038/nri2524

109. Hassan J, Dooley S, Hall W. Immunological response to cytomegalovirus in congenitally infected neonates. Clin Exp Immunol (2007) 147(3):465-71. doi:10.1111/j.1365-2249.2007.03302.x

110. Griffiths PD, Stagno S, Pass RF, Smith RJ, Alford CA Jr. Congenital cytomegalovirus infection: diagnostic and prognostic significance of the detection of specific immunoglobulin M antibodies in cord serum. Pediatrics (1982) 69(5):544-9.

111. Ahlfors K, Forsgren M, Griffiths P, Nielsen CM. Comparison of four serological tests for the detection of specific immunoglobulin $\mathrm{M}$ in cord sera of infants congenitally infected with cytomegalovirus. Scand J Infect Dis (1987) 19(3):303-8. doi:10.3109/00365548709018475

112. Siegrist CA, Aspinall R. B-cell responses to vaccination at the extremes of age. Nat Rev Immunol (2009) 9(3):185-94. doi:10.1038/nri2508

113. Luzuriaga K, Holmes D, Hereema A, Wong J, Panicali DL, Sullivan JL. HIV-1specific cytotoxic T lymphocyte responses in the first year of life. J Immunol (1995) 154(1):433-43.
114. Sandberg JK, Fast NM, Jordan KA, Furlan SN, Barbour JD, Fennelly G, et al. HIV-specific CD8 $+\mathrm{T}$ cell function in children with vertically acquired HIV-1 infection is critically influenced by age and the state of the CD4+ T cell compartment. J Immunol (2003) 170(8):4403-10. doi:10.4049/jimmunol.170. 8.4403

115. Lohman BL, Slyker JA, Richardson BA, Farquhar C, Mabuka JM, Crudder C, et al. Longitudinal assessment of human immunodeficiency virus type 1 (HIV1)-specific gamma interferon responses during the first year of life in HIV-1infected infants. J Virol (2005) 79(13):8121-30. doi:10.1128/JVI.79.13.81218130.2005

116. Hermann E, Truyens C, Alonso-Vega C, Even J, Rodriguez P, Berthe A, et al. Human fetuses are able to mount an adultlike CD8 T-cell response. Blood (2002) 100(6):2153-8.

117. Chapey E, Wallon M, Debize G, Rabilloud M, Peyron F. Diagnosis of congenital toxoplasmosis by using a whole-blood gamma interferon release assay. J Clin Microbiol (2010) 48(1):41-5. doi:10.1128/JCM.01903-09

118. Prendergast AJ, Klenerman P, Goulder PJ. The impact of differential antiviral immunity in children and adults. Nat Rev Immunol (2012) 12(9):636-48. doi: $10.1038 /$ nri3277

119. Hayday AC. Gammadelta T cells and the lymphoid stress-surveillance response. Immunity (2009) 31(2):184-96. doi:10.1016/j.immuni.2009.08.006

120. Ismaili J, Olislagers V, Poupot R, Fournié JJ, Goldman M. Human gamma delta T cells induce dendritic cell maturation. Clin Immunol (2002) 103(3 Pt 1):296-302. doi:10.1006/clim.2002.5218

121. Caccamo N, Sireci G, Meraviglia S, Dieli F, Ivanyi J, Salerno A. Gammadelta $\mathrm{T}$ cells condition dendritic cells in vivo for priming pulmonary CD8 $\mathrm{T}$ cell responses against Mycobacterium tuberculosis. Eur J Immunol (2006) 36(10):2681-90. doi:10.1002/eji.200636220

122. Munz C, Steinman RM, Fujii S. Dendritic cell maturation by innate lymphocytes: coordinated stimulation of innate and adaptive immunity. J Exp Med (2005) 202(2):203-7. doi:10.1084/jem.20050810

123. Mold JE, Michaëlsson J, Burt TD, Muench MO, Beckerman KP, Busch MP, et al. Maternal alloantigens promote the development of tolerogenic fetal regulatory T cells in utero. Science (2008) 322(5907):1562-5. doi:10.1126/science.1164511

124. Elahi S, Ertelt JM, Kinder JM, Jiang TT, Zhang X, Xin L, et al. Immunosuppressive CD71+ erythroid cells compromise neonatal host defence against infection. Nature (2013) 504(7478):158-62. doi:10.1038/nature12675

125. Gavin MA, Bevan MJ. Increased peptide promiscuity provides a rationale for the lack of $\mathrm{N}$ regions in the neonatal $\mathrm{T}$ cell repertoire. Immunity (1995) 3(6):793-800. doi:10.1016/1074-7613(95)90068-3

126. Bodger MP, Janossy G, Bollum FJ, Burford GD, Hoffbrand AV. The ontogeny of terminal deoxynucleotidyl transferase positive cells in the human fetus. Blood (1983) 61(6):1125-31.

127. Klarenbeek PL, Remmerswaal EB, ten Berge IJ, Doorenspleet ME, van Schaik $\mathrm{BD}$, Esveldt RE, et al. Deep sequencing of antiviral T-cell responses to HCMV and EBV in humans reveals a stable repertoire that is maintained for many years. PLoS Pathog (2012) 8(9):e1002889. doi:10.1371/journal.ppat.1002889

128. Smith NL, Wissink E, Wang J, Pinello JF, Davenport MP, Grimson A, et al. Rapid proliferation and differentiation impairs the development of memory CD8+ T cells in early life. J Immunol (2014) 193(1):177-84. doi:10.4049/jimmunol. 1400553

129. PrabhuDas M, Adkins B, Gans H, King C, Levy O, Ramilo O, et al. Challenges in infant immunity: implications for responses to infection and vaccines. Nat Immunol (2011) 12(3):189-94. doi:10.1038/ni0311- 189

130. Antoine P, Varner V, Carville A, Connole M, Marchant A, Kaur A. Postnatal acquisition of primary rhesus cytomegalovirus infection is associated with prolonged virus shedding and impaired CD4+ T lymphocyte function. J Infect Dis (2014) 210(7):1090-9. doi:10.1093/infdis/jiu215

131. Slavuljica I, Kveštak D, Csaba Huszthy P, Kosmac K, Britt WJ, Jonjic S. Immunobiology of congenital cytomegalovirus infection of the central nervous system-the murine cytomegalovirus model. Cell Mol Immunol (2014). doi: $10.1038 / \mathrm{cmi} .2014 .51$

132. Gabrielli L, Bonasoni MP, Santini D, Piccirilli G, Chiereghin A, Petrisli E, et al. Congenital cytomegalovirus infection: patterns of fetal brain damage. Clin Microbiol Infect (2012) 18(10):E419-27. doi:10.1111/j.1469-0691.2012. 03983.x

133. Swanson EC, Schleiss MR. Congenital cytomegalovirus infection: new prospects for prevention and therapy. Pediatr Clin North Am (2013) 60(2):335-49. doi:10.1016/j.pcl.2012.12.008 
Conflict of Interest Statement: The authors declare that the research was conducted in the absence of any commercial or financial relationships that could be construed as a potential conflict of interest.

Received: 28 August 2014; accepted: 16 October 2014; published online: 30 October 2014.

Citation: Huygens A, Dauby N, Vermijlen D and Marchant A (2014) Immunity to cytomegalovirus in early life. Front. Immunol. 5:552. doi: 10.3389/fimmu.2014.00552
This article was submitted to Immunotherapies and Vaccines, a section of the journal Frontiers in Immunology.

Copyright (c) 2014 Huygens, Dauby, Vermijlen and Marchant. This is an open-access article distributed under the terms of the Creative Commons Attribution License (CC

BY). The use, distribution or reproduction in other forums is permitted, provided the original author(s) or licensor are credited and that the original publication in this journal is cited, in accordance with accepted academic practice. No use, distribution or reproduction is permitted which does not comply with these terms. 